\title{
Motivations for self-employment: The case of Maori in New Zealand
}

Fox, Mark pg. 57

\section{Motivations for Self-Employment: The Case of Maori in New Zealand}

\section{Mark Fox}

This article adds to the knowledge of ethnic entrepreneurship by examining differences in motivations for selfemployment between Maori and non-Maori in New Zealand. Some significant differences in motivations are found. Explanations for these differences are provided with reference to previous literature and the culture of Maori.

$\mathbf{M}$ aori, the indigenous persons of New Zealand, are clearly disadvantaged in a number of areas, including education, health care, home ownership, and employment status. ' With regard to employment, Maori have a high incidence of unemployment and usually work in lower paying industries. ${ }^{2}$ In addition, they are less likely to be self-employed than are non-Maori. The most recent and comprehensive data on self-employment in New Zealand are found in the Census of Population and Dwellings 1996 (see Exhibit 1). Maori comprised only 5.4 percent of all self-employed New Zealanders. This statistic is particularly low when one considers that 10.8 percent of the employed persons are Maori.

Two self-employment rates are also shown in Exhibit 1. The more narrowly defined self-employment rate (SE1) is simply the number of people who are self-employed divid ed by the number who are employed, multiplied by 100 . SE1 for Maori was only 9.5 percent, compared to a significantly higher 20.0 percent for non-Maori. Looking at SE1 by both ethnicity and gender, non-Maori men have the highest self-employment rate $(25.6 \%)$, followed by nonMaori women $(13.3 \%)$, Maori men $(12.0 \%)$, and Maori women $(6.4 \%)$.

The second, and broader, self-employment rate (SE2) shown in Exhibit 1 is calculated by dividing the number of persons who are self-employed by the labor force. SE2 for Maori was only 7.8 percent, compared to a significantly higher 18.7 percent for non-Maori. Looking at SE2 by both ethnicity and gender, non-Maori men have the highest selfemployment rate $(24.1 \%)$, followed by non-Maori women $(12.4 \%)$, Maori men $(10.1 \%)$, and Maori women $(5.2 \%)$. These data indicate that if a Maori person is employed, he or she is considerably less likely than non-Maori to be selfemployed.

Given that Maori are underrepresented among the selfemployed in New Zealand, the question arises as to why this is the case. This article focuses on the motivations or reasons that Maori have for becoming self-employed. The rationale for examining these motivations to start a busi- ness is provided by Hamilton, who comments that "... an understanding of motivation is important if we are interested in developing policies to stimulate the flow of new ventures." An investigation of the motivations of self-employed Maori who have established their own businesses may point to ways to remedy the imbalance between Maori and non-Maori in the area of self-employment. Furthermore, differences in motivations may also help explain the disparity in self-employment status for Maori versus non-Maori, and for men versus women.

\section{Literature Review}

The literature on what motivates people to become selfemployed invariably distinguishes between push and pull factors. Push factors are viewed as things that people are unhappy with in their current situations that may lead them to become self-employed. In this regard, Brockhaus has found that entrepreneurs were less satisfied with their work, coworkers, supervision, and promotion opportunity in their previous positions than a control group of transferred and promoted managers. ${ }^{4}$ In their study of 468 women entrepreneurs in 18 U.S. states, Hisrich and Brush similarly found that 42 percent cited job frustration as a major reason for becoming involved with their current entrepreneurial ventures. ${ }^{5}$

In contrast, pull factors are reasons that attract people to becoming an entrepreneur. Pull factors include the rewards associated with entrepreneurship (e.g., independence, achievement, and making the most of a market opportunity). ${ }^{6}$

Both push and pull factors may coalesce to bring about a person's decision to become self-employed. For example, in a sample of 65 enterprises, Baker divides reasons for business formation into push and pull factors. ${ }^{7}$ The major push factor was dissatisfaction with previous employment (mentioned by $28 \%$ of the respondents) and unemployment/redundancy (given by $22 \%$ ). The respondents major pull factors were cited as businesses opportunity (25\%), independence $(35 \%)$, and to make money $(25 \%)$.

Four studies have examined the motives of New Zealanders to become self-employed. ${ }^{8}$ Hamilton looks at the motivations of three groups of business founders (those that established businesses in 1970-71, 1975-76 and 1980-81). He finds that the major motives were to "make the most of a commercial opportunity" (cited as important by $39.8 \%$ of his sample in 1980-81) and "to give the founders their independence" (cited as important by $32.7 \%$ 


\section{Exhibit 1}

\section{Statistics on Self-Employed New Zealanders}

\begin{tabular}{|c|c|c|c|c|c|c|c|c|}
\hline & \multicolumn{2}{|c|}{ Self-Employed } & \multicolumn{2}{|c|}{ Employed Persons } & \multicolumn{2}{|c|}{ Labor Force } & \multirow[t]{2}{*}{$\begin{array}{l}\text { Self-Employed } \\
\text { as a \% of } \\
\text { Employed } \\
\text { Persons (SE1) }\end{array}$} & \multirow[t]{2}{*}{$\begin{array}{c}\text { Self-Employed } \\
\text { as \% of } \\
\text { Labor Force } \\
\text { (SE2) }\end{array}$} \\
\hline & No. & $\%$ & No. & $\%$ & No. & $\%$ & & \\
\hline Maori men & 11,610 & 3.8 & 96,708 & 5.9 & 115,305 & 6.5 & 12.0 & 10.1 \\
\hline Maori women & 5,097 & 1.7 & 79,656 & 4.9 & 98,358 & 5.6 & 6.4 & 5.2 \\
\hline Non-Maori men & 203,070 & 65.9 & 793,305 & 48.6 & 843,906 & 47.8 & 25.6 & 24.1 \\
\hline Non-Maori women & 87,897 & 28.6 & 661,152 & 40.5 & 709,758 & 40.2 & 13.3 & 12.4 \\
\hline \multicolumn{9}{|l|}{ Totals } \\
\hline Maori & 16,707 & 5.4 & 176,361 & 10.8 & 213,663 & 12.1 & 9.5 & 7.8 \\
\hline \multirow[t]{2}{*}{ Non-Maori } & 290,967 & 94.5 & $1,454,460$ & 89.2 & $1,553,664$ & 87.9 & 20.0 & 18.7 \\
\hline & 307,674 & 100.0 & $1,630,821$ & 100.0 & $1,767,327$ & 100.0 & 18.9 & 17.4 \\
\hline
\end{tabular}

Source: Census of Population and Dwellings 1996.

of the founders in 1980-81). The only study of motivations of Maori to become self-employed is by Simpson and Raumati. In examining the motives of 42 Maori women businessowners, these researchers identify three motivations ("independence and flexibility," the "opportunity to be creative," and the "opportunity to earn more money") as more or less equally major reasons for Maori women to start a business (see Exhibit 2).

Shane, Kolvereid, and Westhead also studied motivations of business founders in New Zealand. Their survey of 138 founders of new firms indicates that the major reasons

\begin{tabular}{|lcc|}
\hline \multicolumn{3}{|c|}{ Exhibit 2 } \\
\hline Motivations of Maori Businesswomen \\
\hline Reason for Starting Business & No. & $\%$ \\
Independence and flexibility & 23 & 55 \\
Opportunity to be creative through work & 22 & 52 \\
Opportunity to earn more money & 22 & 52 \\
Tired of working for someone else & 14 & 33 \\
To meet a particular service or need & 13 & 31 \\
All other & 18 & 43 \\
Source: Simpson and Raumati (1991, p. 26). & \\
\hline
\end{tabular}

for business formation were related to independence ("to control my own time," "to have greater flexibility for my personal and family life," and "to have considerable freedom to adapt my own approach to work"). Lawrence and Hamilton's research presents the most recent study of influences on small business formation in New Zealand. These authors updated Hamilton's 1987 study. The updated research was based on a survey of 267 small business owners, with the authors concluding:

These data show up more clearly the increasingly pervasive influence of unemployment or the threat of this on business founders: almost half $(47 \%)$ of the founders in $1990-91$ period admitted to having been influenced by this. The increases in the proportion affected between 1970-71 and 1980-81 (up 15 percentage points) and between 1980-81 and 1990-91 (up a further 21 points) are both statistically significant at the 1 percent level. While it remains evident that New Zealand founders pulled into business formation by three motivations: commercial opportunity, independence, and wealth creation, there is clear evidence that the push of unemployment has grown to be the main influence in about one-fifth of start-ups and a consideration in almost half of all decisions to become self-employed. ${ }^{9}$ 


\section{Method}

The research method adopted for this study involved a questionnaire that was mailed to 210 self-employed Maori whose names were on the Maori Business Owners Database. This database was created specifically for the research undertaken. The initial task in creating this database was the identification of Maori businessowners. This proved to be a difficult and time-consuming process. Several government agencies, which one could reasonably expect to have lists of self-employed Maori, were contacted. Te Puni Kokiri at the Ministry of Maori Development noted that his agency had attempted to compile such a list, but had been unsuccessful, obtaining only 29 names in the process. The Ministry of Women's Affairs provided a copy of the Directory of Maori Women Business Owners. The names of self-employed Maori women in this directory subsequently formed part of the database. The Business Development Boards and Poutama Trust (an organization largely concerned with providing advice and assistance to potential Maori businessowners) provided additional names. Of the 210 questionnaires mailed, 79 usable responses were received ( 33 from women and 46 from men), resulting in an overall response rate of 38 percent. The survey used was the same as the motivation section of the questionnaire used by Austin, Fox and Hamilton. ${ }^{10}$ Thus, comparisons could be made between data collected in the earlier study and the present one.

\section{Results and Discussion}

This section examines the principal motivations for starting a business as well as the gender and principal motivations for business establishment.

\section{Principal Motivations for Starting a Business}

The principal motivations that self-employed Maori give for starting their businesses are shown in Exhibit 3 (principal motivations are those rated first, or first-equal, by respondents). These motivations are compared with data from a recent study relating to the principal motivations for selfemployed New Zealanders who are not Maori."

Exhibit 3 makes it clear that some significant differences exist in the proportions of self-employed Maori versus nonMaori in some motivational categories. The major motivation for both self-employed Maori and non-Maori was to make the most of a commercial opportunity. However, a significantly higher proportion of self-employed Maori (45.6\%) cited making the most of a commercial opportunity as their principal motivation; only 32.6 percent of non-Maori cited this motivation. Self-employed Maori were also significantly more likely than non-Maori to start their own business in order to avoid unemployment or the threat thereof; $27.8 \%$ of the Maori sample identified this motivation, compared to only $9.2 \%$ of the non-Maori sample.

When compared to non-Maori, Maori are significantly less likely to establish their own business in order to give

\begin{tabular}{|c|c|c|c|c|c|}
\hline \multicolumn{6}{|c|}{$\begin{array}{c}\text { Exhibit } 3 \\
\text { Principal Motivations of Self-Employed New Zealanders, Maori versus non-Maori }\end{array}$} \\
\hline & & & \multicolumn{3}{|c|}{ • } \\
\hline & \multicolumn{2}{|c|}{$\begin{array}{l}\text { Maori } \\
(n=79)\end{array}$} & \multicolumn{2}{|c|}{$\begin{array}{c}\text { Non-Maori } \\
(n=196)\end{array}$} & \multirow[t]{2}{*}{ z-statistic } \\
\hline Principal Motivation & No. & $\%$ & No. & $\%$ & \\
\hline To make the most of a commercial opportunity & 36 & 45.6 & 64 & 32.6 & $2.02^{b}$ \\
\hline To avoid unemployment or the threat of unemployment & 22 & 27.8 & 18 & 9.2 & $3.97^{\circ}$ \\
\hline To give the founder(s) independence & 18 & 22.8 & 71 & 36.2 & $-2.16^{b}$ \\
\hline To escape an unfulfilling job & 1 & 1.3 & 14 & 7.1 & $1.94^{\mathrm{a}}$ \\
\hline To create wealth for the founder(s) & 9 & 11.4 & 37 & 18.9 & -1.51 \\
\hline To formalise profit sharing among partners & 1 & 1.3 & 4 & 2.0 & -0.44 \\
\hline All other reasons & 17 & 21.5 & 14 & 7.1 & $3.41 \mathrm{c}$ \\
\hline $\begin{array}{l}\text { a. } p<.10 \% \\
\text { b. } p<.05 \% \\
\text { c. } p<.01 \%\end{array}$ & & & & & \\
\hline
\end{tabular}


themselves independence; 22.8 percent of Maori cited this motivation compared to 36.2 percent of non-Maori. Although not a major motivation for either group, one can infer that-compared to non-Maori-Maori are significantly less likely to establish their own business in order to escape an unfulfilling job; 1.3 percent of the Maori sample cited this motivation, compared to 7.1 percent of nonMaori.

\section{Gender and Principal Motivations for Business Establishment}

One possible explanation for the finding that there are differences in motivations of Maori versus non-Maori lies in the composition of the samples compared. If motivation differs between self-employed men and women, then the sample of self-employed Maori, given its bias towards Maori women, may have misrepresented the motivation for self-employed Maori as a whole. This study's 79 selfemployed Maori comprised 33 women $(42 \%)$, whereas only 31 percent of total Maori self-employed are women (see Exhibit 1).

However, when comparing self-employed Maori on the basis of gender, one finds no statistically significant differences between the two groups (see Exhibit 4). Unfortunately, the gender makeup of the non-Maori group in Exhibit 3 is unknown, so one cannot perform a similar analysis for that group. However, a previous study on motivations of male versus female entrepreneurs in New Zealand found no differences in the motivations of male versus female self-employed. ${ }^{12}$

\section{Discussion and Conclusions}

This study set out to discover whether there were differences in the motivations of Maori versus non-Maori businessowners in New Zealand. It found that significant differences do exist. Before providing some possible expla- nations for these findings, one must consider the differences in motivations found in this sample compared to the only other extant study of Maori businessowners, namely Simpson and Raumati's study of women businessowners. ${ }^{13}$

Exhibit 4 indicates the principal motivations of Maori women in Simpson and Raumati's sample were to "make the most of a commercial opportunity" (39.4\%) or to "avoid unemployment or the threat of unemployment" $(27.3 \%)$. One can view Simpson and Raumati's category "to meet a particular service or need" as similar to the category "to make the most of a commercial opportunity" identified in this investigation. It is, therefore, somewhat surprising that the women in this sample ranked this motivation foremost, whereas Simpson and Raumati's sample ranks it only fifth. Other disparities between this study and Simpson and Raumati's derive from the difference between their category of "independence and flexibility" (55\%) and the category of "to give the founder(s) independence" (30.3\%), cited in this study. Also, the unemployment issue does not appear in Simpson and Raumati's sample.

These differences can be explained in at least two ways. First, they may be attributable to changes in the motivations of self-employed women over time. This seems unlikely, however, since an earlier New Zealand study by Hamilton suggests that rankings given motives to become self-employed do not change over time. ${ }^{14}$ The second, and the more likely, explanation of the observed differences is that they are attributable to differences in sampling. Simpson and Raumati's sample may represent a more experienced group of women entering self-employment (hence these women's concern about self-employment as a means of providing a creative outlet and their not mentioning and a lack of concern for self-employment as a means to avoid unemployment or the threat thereof).

A recent literature review by Cooper Maysami and Goby proposes:

\begin{tabular}{|c|c|c|c|c|c|}
\hline \multicolumn{6}{|c|}{$\begin{array}{c}\text { Exhibit } 4 \\
\text { Principal Motivations of Self-employed Maori Men and Women }\end{array}$} \\
\hline \multirow[b]{2}{*}{ Principal Motivation } & \multicolumn{2}{|c|}{$\begin{array}{c}\text { Men } \\
(n=46)\end{array}$} & \multicolumn{2}{|c|}{$\begin{array}{c}\text { Women } \\
(n=33)\end{array}$} & \multirow[t]{2}{*}{ z-statistic } \\
\hline & No. & $\%$ & No. & $\%$ & \\
\hline To make the most of a commercial opportunity & 23 & 50.0 & 13 & 39.4 & 0.93 \\
\hline To avoid unemployment or the threat of unemployment & 13 & 28.2 & 9 & 27.3 & 0.10 \\
\hline To create wealth for the founder(s) & 6 & 13.0 & 3 & 9.1 & 0.55 \\
\hline To give the founder(s) independence & 8 & 17.4 & 10 & 30.3 & -1.35 \\
\hline All other reasons & 9 & 19.6 & 10 & 30.3 & -1.61 \\
\hline
\end{tabular}


In general, as opposed to men (who are usually motivated by material rewards), women are primarily motivated by the need for independence (Hisrich and Brush 1986). Lee-Gosselin and Grise (1990, p. 432) note that for women businessowners, the idea to start a business originates almost exclusively from the desire to "... fulfill an old dream, a desire for recognition by others, the desire to put one's knowledge and skills to use, a continuity to training or work experience, or the desire to be independent and have control over one's life."15

These observations do not hold true for New Zealand. First, the major motivating factor for non-Maori was not material rewards, but gaining independence. For Maori, the major motivating factor was making the most of a commercial opportunity. However, there were no differences in motivations between Maori men and Maori women (see Exhibit 4), with both groups being primarily motivated by the desire to make the most of a commercial opportunity.

One can identify a number of perspectives that help explain the differences in motives between Maori and nonMaori in becoming self-employed. Indeed, it is likely that such perspectives taken together go some way towards explaining the observed differences.

Cultural factors help provide one explanation as to why the motives of Maori and non-Maori to become selfemployed differ. The evolution of Maori society has tended not to focus on the individual, but on the whanau (extended family). Indeed, within the Maori culture, individuals typically did not make decisions based on self-interest, but rather with reference to the whanau, hapu (sub-tribe) or iwi (tribe). Many Moari-to some extent-still hold this cultural imperative. This factor may help explain, why, when compared to non-Maori, Maori demonstrate a lesser need to become self-employed in order to gain or display independence.

One finding of this study is that avoiding unemployment or the threat thereof constitutes a greater motivator for Maori compared to non-Maori in becoming self-employed. It is likely that the higher rate of unemployment among Maori accounts for this difference (see Exhibit 5). The rate of unemployment for both Maori men and women is double that for, respectively, non-Maori men and women. It is hardly surprising that Maori cite unemployment as a more important consideration in the decision to become selfemployed, compared to non-Maori.

Social learning theory provides another explanation for this study's findings. It proposes that one way people learn is by observing others. In this theory, a role model is rewarded or punished, hence learning takes place through observation, or vicariously. ${ }^{16}$ If this concept is applied to entrepreneurship, children (observers) see their parents

\begin{tabular}{|ccccc|}
\hline \multicolumn{5}{|c|}{ Exhibit 5 } \\
Unemployment Rates (\%) by Gender for \\
Maori and Non-Maori \\
\hline \multicolumn{5}{|c|}{ Men } \\
\hline Year & Maori & NZ European & Maori & NZ European \\
\hline 1987 & 10.5 & 2.8 & 11.2 & 3.8 \\
1988 & 10.7 & 3.4 & 11.1 & 3.6 \\
1989 & 15.4 & 5.0 & 14.0 & 4.8 \\
1990 & 18.7 & 5.6 & 17.5 & 5.5 \\
1991 & 21.8 & 6.8 & 20.1 & 6.2 \\
1992 & 26.9 & 8.7 & 24.4 & 7.3 \\
1993 & 26.7 & 8.2 & 21.6 & 7.4 \\
1994 & 24.3 & 7.4 & 21.0 & 6.8 \\
1995 & 19.6 & 5.8 & 19.2 & 5.3 \\
1996 & 14.6 & 4.6 & 16.7 & 4.6 \\
1997 & 15.1 & 4.5 & 15.8 & 4.7 \\
\hline Source: Statistics & New Zealand, Labour Market 97. \\
\hline
\end{tabular}

(role models) gaining rewards or punishment for their entrepreneurial endeavours and make assessments about the desirability of entrepreneurship for themselves based on these observations. Scherer, Adams, Carley and Wiebe state that if the observer values the reinforcements "or recognizes the positive outcomes of such behavior, then the observer will attempt to replicate the model's behavior and obtain similar types of reinforcements." ${ }^{\prime 7}$ If. a child has a parent with their own business, and the parent gains rewards (job satisfaction, financial, community recognition, etc.) for these efforts, and the child sees and values these rewards, then he or she, is more likely to view self-employment as desirable.

With regards to the decision to become self-employed, the critical models for this choice are often parents, but they may also be siblings, relatives, or friends. The importance of parents as role models in the United Kingdom was espoused in the influential 1971 Bolton Report.

$\ldots$ it is our impression that the general climate of opinion is now so antipathetic to business and particularly small business that except for those whose father is in business on his own account and for whom entry into small business is not only encouraged, but relatively easy, the tendency for young people not to adopt independent business as a career. ${ }^{18}$ 
More recently, Stanworth, Stanworth, Granger, and Blyth ${ }^{19}$ found that 43 percent of London-based businessowners had either a mother or father (or both) who were in business. Also, Scherer et al. found in their study of 366 junior and senior business administration students that "the presence of a parent entrepreneurial role model is associated with increased education and training aspirations, task self-efficacy, and expectancy for an entrepreneurial career."20

As Maori are underrepresented among the selfemployed compared to non-Maori, there will be proportionately fewer parental role models for Maori children compared to non-Maori children. Therefore, Maori children are less likely to have a key role model in the first instance. Supposing such a role model is present, then one must consider the issues of whether the observer-a Maori child-values the behavior shown by the parents and sees desirable outcomes from this behavior. The research undertaken in this study indicates that a key value of being self-employed for non-Maori, namely independence, is not so valued by non-Maori. This study identifies commercial opportunity as the key motivation for Maori to become self- employed.

In terms of valuing outcomes, two possible motivations of Maori to become self-employed, namely to avoid unemployment or the threat of unemployment, will not lead to positive outcomes. It is likely that a person who becomes self-employed because he or she does not want to remain unemployed, or because he or she wants to avoid becoming unemployed, lacks the educational background and skills base as those who become self-employed from a position of already being employed. Such individuals are likely to find coping with the pressures of self-employment more stressful and may experience lower personal and financial rewards from establishing a business.

In conclusion, Maori are underrepresented among the self-employed in New Zealand. The motives for becoming self-employed also differ between Maori and non-Maori. To some extent the lower self-employment rate of Maori may well be a consequence of the cultural values placed on being self-employed. However, a lower prevalence of role models for young Maori may also contribute to this, as well as the fact that Maori are more motivated than non-Maori to become self-employed to escape unemployment.

\section{Endnotes}

1. P. C. Dalziel and M. A. Fox, Ethnic Disparities in Economic Attainment: A Survey of the Economics Literature. Wellington, Te Puni Kokiri, Ministry of Maori Development, 1996.

2. New Zealand Now: Maori. Statistics New Zealand, 1994; and Manatu Maori, Maori and Work: the Position of Maori in the New Zealand Labour Market, 1991.

3. R. T. Hamilton, "Motivations and Aspirations of Business Founders," International Small Business Journal 6, no. 1 (1987), p. 71.

4. R. H. Brockhaus, "The Effect of Job Dissatisfaction on the Decision to Start a Business," Journal of Small Business Management 18, no. 1 (1980), pp. 37-43.

5. R. D. Hisrich and C. Brush, "The Woman Entrepreneur: Implications of Family, Educational and Occupational Experience," Frontiers of Entrepreneurship Research (1983), pp. 255-270.

6. S. Birley and P. Westhead, "A Taxonomy of Business Startup Reasons and their Impact of Firm Growth and Size," Journal of Business Venturing 9 (1994), pp. 7-31; S. Holmes and I. Zimmer, "The Nature of the Small Firm: Understanding the Motivations of Growth and Nongrowth Oriented Owners," Australian Journal of Management 19 (1994), pp. 97-117; R. Gatewood, K. Shaver, and W. Gartner, "A Longitudinal Study of Cognitive Factors Influencing Start-up Behaviours and Successes at Venture Creation," Journal of Business Venturing 10 (1995), pp. 371-391; and W. H. Stewart, W. E. Watson, J. C. Carland, and J. W. Carland, "A Proclivity for Entrepreneurship: A Comparison of Entrepreneurs, Small Businessowners, and Corporate Managers," Journal of Business Venturing 14, no. 2 (1999), pp. 189-214.

7. P. Baker, "Small Firms, Industrial Districts and Power Asymmetries," International Journal of Entrepreneurial Behaviour and Research 1, no. 1, (1995), pp. 8-25.

8. Hamilton, "Motivations and Aspirations of Business Founders"; D. Simpson and H. Raumati, Maori Women in Business: The Issues and Trends They Face When Establishing Their Businesses. Wellington, Ministry of Women's Affairs, 1991; S. Shane, L. Kolvereid, and P. Westhead, "An Exploratory Examination of the Reasons Leading to New Firm Formation Across Country and Gender," Journal of Business Venturing 6 (1991), pp. 431-446; and L. Lawrence and R. T. Hamilton, "Unemployment and New Business Formation," International Small Business Journal, 15, no. 3 (1997), pp. 78-82. 
9. Lawrence and Hamilton, "Unemployment and New Business Formation, p. 81.

10. T. J. Austin, M. A. Fox, and R. T. Hamilton, A Study of Small- and Medium-Sized Business Financing in New Zealand. Report commissioned by the Ministry of Commerce, Wellington, New Zealand, 1996.

11. Ibid.

12. Shane, Kolvereid, and Westhead, "An Exploratory Examination of the Reasons Leading to New Firm Formation Across Country and Gender."

13. Simpson and Raumati, Maori Women in Business: The Issues and Trends They Face When Establishing Their Businesses.

14. Hamilton, "Motivations and Aspirations of Business Founders."

15. R. Cooper Maysami and V. P. Goby, "Female Business Owners in Singapore and Elsewhere: A Review of Studies," Journal of Small Business Management 37, no. 2 (1999), p. 98.

16. A. Bandura, "Social Learning Through Imitation," in M. R. Jones, ed., Nebraska Symposium on Motivation Vol. 10, Lincoln: University of Nebraska Press, 1962; W. R. Woodward, "The 'Discovery' of Social Behaviorism and Social Learning Theory, 1870-1980," American Psychologist 37, no. 4 (1982), pp. 396-410.

17. R. F. Scherer, J. S. Adams, S. S. Carley, and F. A. Wiebe, "Role Model Performance Effects on Development of Entrepreneurial Career Preference," Entrepreneurship: Theory and Practice 13, no. 3 (1989), pp. 53-71.

18. J. Bolton, Report of the Committee of Inquiry on Small Firms. London: HMSO, 1971.

19. J. Stanworth, C. Stanworth, B. Granger, S. and Blyth, "Who Becomes an Entrepreneur?" International Small Business Journal 8, no. 1 (1989), pp. 11-22.

20. Scherer, Adams, Carley, and Wiebe, "Role Model Performance Effects," p. 53.

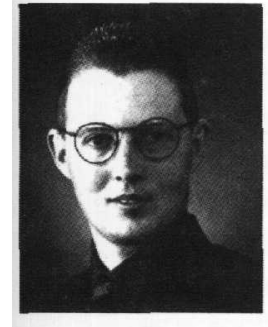

Mark Fox is an associate professor of management and entrepreneurship at Indiana University South Bend. He obtained his Ph.D. from the University of Canterbury in New Zealand and has taught courses in entrepreneurship, venture growth management, and business planning at the graduate and undergraduate levels. His research interests include corporate governance, small firm finance ${ }_{2}$ and management succession.

Dr. Fox has published widely, including papers in the Journal of Management, Psychology and Marketing, International Small Business Journal, International Journal of Entrepreneurial Behavior and Research and Advances in International Banking and Finance. 